\title{
Sero-Prevalence of Bovine Brucellosis and its Associated Risk Factors in Becho District, South West Shewa, Oromia Regional State, Ethiopia
}

\author{
Dinknesh Teka, Biniam Tadesse*, Getachew Kinfe, Yifat Denberga \\ National Animal Health Diagnostic and Investigation Center, Ethiopia \\ Hawassa University, Faculty of Veterinary Medicine, Hawassa, Ethiopia
}

*Corresponding Author: Biniam Tadesse, National Animal Health Diagnostic and Investigation Center, Ethiopia. Email: binimanu10@gmail.com

\begin{abstract}
A cross-sectional study was conducted in selected areas of Becho district, Oromia regional state from December, 2018 to May, 2019 to estimate the sero-prevalence of bovine brucellosis in the study area and identify the associated risk factors for the seropositivity. Simple random sampling method was used for sampling each herd and animal during serum collection, and risk factors accessed through interviewee of the animal owners. A total of 384 serum samples were collected from cattle of above 6 months of age and sera were initially screened with Rose Bengal Plate Test (RBPT) and those samples found positive by RBPT were further tested by Indirect Enzyme-linked Immuno Sorbent Assay (I-ELISA) for confirmation. Based on the result, $13(3.39 \%)$ were positive using RBPT and the overall sero-prevalence of bovine brucellosis at animal-level estimated to be 4(1.04\%) based on I-ELISA result. At herds' level, an overall sero-prevalence of 5.48\% was obtained. Pearson's Chi-square revealed that the presence of abortion history, retained fetal membrane and breed type were significantly associated with the seropositivity of bovine brucellosis $(p<0.05)$ with Chi-square value of 38.2, 5.76 and 3.99 and $P$-value of 0.000, 0.016 and 0.046, respectively. The odds of having brucellosis increased by 12.4 times in cow with history of abortion compared to cow without the history, increased by 4.5 times in the animal suffered from history of retained placenta compared to cow with no history of retained placenta and 3.1 times in cross-breed than indigenous breeds. In conclusion, the study demonstrate that the prevalence of bovine brucellosis was low in Becho district. However, poor understanding of brucellosis among communities and a high level of risky practice might result in an increased transmission between animals and zoonoses in risky group personnels. Thus, awareness creation about impacts of the disease, zoonotic importance, risk factors and method of prevention were recommended.
\end{abstract}

Keywords: Bovine brucellosis, cattle, I-ELISA, RBPT, Risk factors, sero-prevalence

\section{INTRODUCTION}

Brucellosis is a highly contagious, zoonotic and economically important bacterial disease of animals worldwide and it is considered as one of the most widespread zoonosis in the world (Asgedom et al., 2016). The disease affects domestic animals (cattle, sheep, goat, camel and pig), human and wildlife (Takele, 2016). Bovine brucellosis usually caused by Brucella abortus and occasionally by B. melitensis and B.suis (Megersa et al., 2012; Kebede et al., 2008), all of which are facultative intracellular, gramnegative, non-motile, partially acid-fast coccobacilli that lacks capsule or endospores.

The disease is characterized by trimester abortion at first gestation, weak calves, still birth, endomertitis, infertility, reduced milk production and is mainly caused by biovars (mainly biotype-
1) of B. abortus (Geresu et al., 2016; OIE, 2008), whereas bulls can develop orchitis, epididymitis, seminal vasiculitis and sterility (Megid et al., 2010; Kebede et al., 2008). Furthermore, since brucellosis is an important cause of abortion especially in first calf heifers, the disease can also cause important economic losses in developing countries (Megersa et al., 2012).

The most common route of transmission is ingestion of contaminated pasture, feed, fodder, water, and after birth; aborted fetuses, uterine discharges and new born calves, which contains large doses of infectious organism and constitutes a very important source of infection (Geresu et al., 2016). However, infection through injured/intact skin, the mucosa at the respiratory system and conjunctiva frequently occurs (Tesfaye et al., 2017; Radostits et al., 2007). 
Sero-Prevalence of Bovine Brucellosis and its Associated Risk Factors in Becho District, South West Shewa, Oromia Regional State, Ethiopia

Although the livestock sector in Ethiopia has a significant contribution to the national economy; productivity (meat and milk) per animal is very low, majorly due to technical constraints and disease like brucellosis (Shiferaw et al., 2003). A large number of studies on bovine have been reporting brucellosis sero-prevalence ranging from 0 to $50 \%$ in intensive management systems (Lakew et al., 2019; Yohannes et al., 2013; Alem and Solomon, 2002; Belihu, 2002) and 0.05 to $15.2 \%$ in extensive management systems (Garoma, 2018; Degefa et al., 2011).

Sero-prevalence of bovine brucellosis had been established in different parts of the country, but still there is no online information on status of the disease in Becho district. Further assessment of the status of disease and the associated risk factors has paramount importance that can be used for research, control and prevention of brucellosis in Ethiopia as general and specifically in the study site. Hence, the current study was undertaken to to estimate the sero-prevalence of bovine brucellosis and to assess the risk factors

associated with bovine brucellosis in Becho district.

\section{Materials ANd Methods}

\subsection{Study Area}

The study was conducted in Becho district, Oromia regional state, central Ethiopia, which is located at $80 \mathrm{kms}$ South-West of Addis Ababa, at an altitude of 2,193 meters above sea level. Its annual temperature is $17.2^{\circ} \mathrm{C}$ and the mean annual rainfall is $1,148 \mathrm{~mm}$ (NMSA, 2011). The livestock population of the area includes 101,282 cattle, 21,631 sheep, 19,521 goats and 20,954 equines according to $2010 \mathrm{EC}$ data from Office of Livestock Development and Resources of the Becho district. The town has human population density of 99,090 (CSA, 2013). The area was selected based on gap of no previous published literature on the prevalence of bovine brucellosis. Geographically, the study areas cover latitude and longitude ranges of $8^{\circ} 31^{\prime}$ to $8^{\circ} 45^{\prime}$ North and $38^{\circ} 7.5^{\prime}$ to $38^{\circ} 24.5^{\prime}$ East respectively. The district having the study area found is briefly sketched as illustrated in (Figure 1).

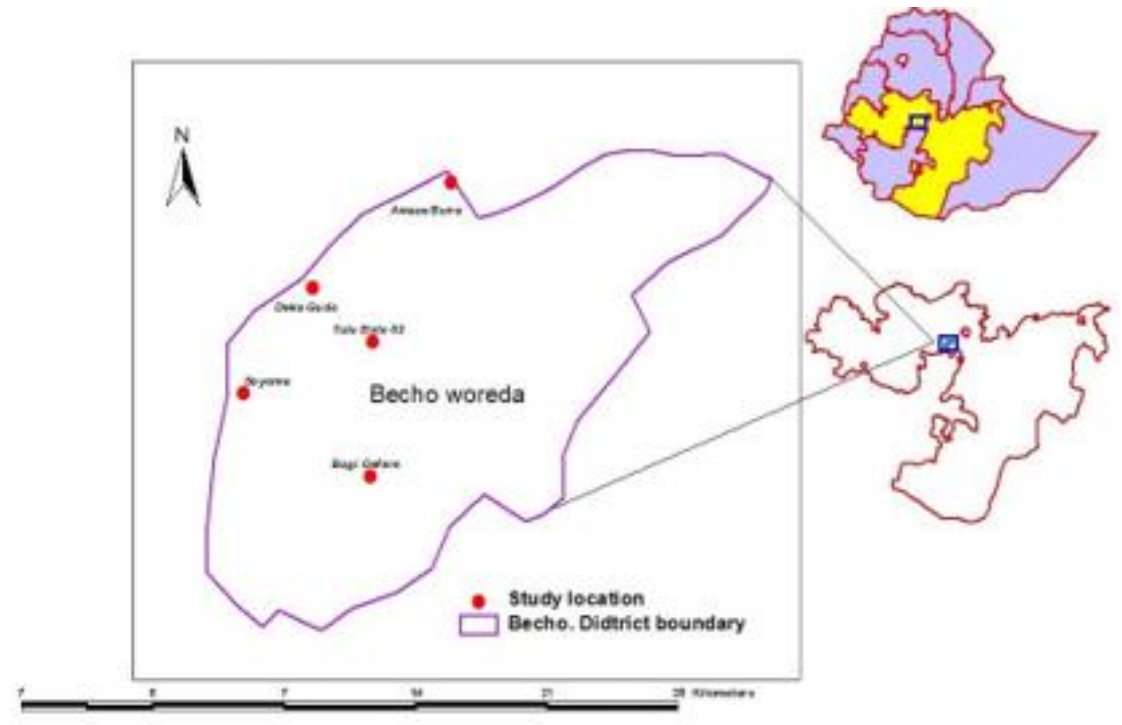

Figure1. Map of Ethiopian showing the study area

\subsection{Study Populations}

The target populations consisted of cattle that were managed under the extensive and semiintensive (mixed-crop livestock) production system. The cattle under study comprised of the local breeds and cross breeds with no history of vaccination against brucellosis. Both sexes and different age group greater than six month were included in the study as the disease was not common in the cattle less than 6 months of age due to maternal antibody. Individual animals were categorized as young ( $\leq 36$ months) and adult ( $>36$ months) according to (Geresu et al., 2016).

\subsection{Study Design and Method}

A cross-sectional sero-prevalence study and questionnaire survey of bovine brucellosis was conducted in selected areas of Becho district from December, 2018 to May, 2019 to determine the sero-prevalence of bovine Brucella infection in cattle and to estimate the associated risk factors for the seropositivity. Simple random 
sampling method was implied to sample herds and individual animals.

\subsection{Sampling Methodology and Sample Size Determination}

The list of householders/animal owners was obtained from Office of Livestock Development and Resources of the Becho district. Since herds were regarded as the primary sampling units, 73 herds were selected randomly from one urban and four rural kebeles based on sampling frame. The herd sizes were classified in to small (1-15 animals), medium (16-30 animals) and large (> 30 animals) according to number of animals within the herd according to (Megersa et al., 2011b). The individual animal sampling activities were done using the simple random sampling.

To determine the sample size, an expected prevalence of $50 \%$ was taken into consideration since there was no online information about the status the disease at Becho district beforehand. The desired sample size for the study was calculated using the formula given by (Thrusfield, 2018) with 95\% confidence interval and $5 \%$ absolute precision.

$$
n=\frac{Z^{2} * P_{\exp } *\left(1-P_{\exp }\right)}{d^{2}}
$$

Where $\mathrm{n}=$ required sample size, $\mathrm{Z}=$ reliability coefficient $(1.96$ at $\mathrm{d}=0.05$ or $95 \% \mathrm{CI}), \mathrm{P}_{\exp }=$ expected prevalence $(50 \%)$ and $\mathrm{d}=$ desired absolute precision $(95 \% \mathrm{CI})$.

$$
n=\frac{1.96^{2} * 0.5 *(1-0.5)}{0.05}=384
$$

Therefore, the total numbers of animal to be sampled from the area were 384 .

\subsection{Sample Collection and Submission}

\subsubsection{Questionnaire Survey}

Parallel to collection of serum samples, a structured questionnaire survey (Annex 2) was administered to respondents whose cattle were included in the study through interviewee by local language. The questionnaire was focused on herd-level covariates such as herd size, categorized as small, medium and large, the presence of separated calving pen, source of replacement stock (raise own farm, market or both), abortion history, history of retained fetal membrane, management system (extensive and semi-intensive) and ways of keeping livestock (keep all species together and separate all species
In different barn) were recorded. The method of disposing placenta and aborted fetus was categorized into deep bury, dispose into the environment and allow to eaten by carnivores. Awareness of the owners about brucellosis was also coded.

\subsubsection{Sample Collection and Transportation}

Blood samples were collected aseptically from jugular vein of individual animals selected during sampling for serological survey purpose. Thus, from each selected animal, approximately $10 \mathrm{ml}$ of blood was collected using plain vacutainer tubes and needle. Identification for each of the animal was labeled on corresponding vacutainer tube. The collected blood samples were kept overnight to allow clotting in slant position at room temperature at Becho wereda veterinary clinic. Then, the sera were carefully decanted into $1.8 \mathrm{ml}$ labeled cryovials without mixing with the clotted blood. The harvested sera were then taken to National Animal Health Diagnostic and Investigation Center (NAHDIC), bacterial serology laboratory using icebox, and stored at $20^{\circ} \mathrm{C}$ until further processing.

Information regarding the individual animal attributes such as kebele, breed, sex, age, abortion history, pregnancy and parital status of each sampled animals was recorded along the blood collected (Annex 1).

\subsection{Serological Diagnostic Tests}

\subsubsection{Rose Bengal Plate Test}

All serum samples collected were screened using RBPT according the procedures described by the World Organization for Animal Health (OIE, 2004) and manufactures' instruction. RBPT contains Brucella antigen strain 99 (from ID.vet, RSA-RB-016, 0112 GB, 310, rue Louis PasteurGrables- FRANCE). Before performing the test, antigen and sera were taken out of refrigerator and left at room temperature for half an hour before the test commences to maintain to room temperature and processed following the recommended procedures. Briefly, $30 \mu \mathrm{l}$ of sera samples were dispensed on to the plate, and the same volume of RBPT antigen were dropped alongside the sera. The antigen and the sera was then mixed thoroughly by using an applicator stick, the plate was shacked for about 4 minutes, and examined for agglutination immediately after the mentioned minute (Annex 3). 
Sero-Prevalence of Bovine Brucellosis and its Associated Risk Factors in Becho District, South West Shewa, Oromia Regional State, Ethiopia

\subsubsection{Indirect Enzyme-Linked Immuno Sorbent Assay (I-ELISA)}

For further analysis of RBPT positive samples, IELISA was performed using a commercial IELISA kit (from ID.vet, BRUS-MS-5P, C35, 1014 GB, 310, rue Louis Pasture- Grables FRANCE) to detect antibodies directed against brucella abortus in cattle serum sample, and the protocol provided by the developers and (OIE, 2004) was followed precisely. Before performing the test, the serum and all reagents taken out of the refrigerator and left at room temperature for half an hour and homogenized by inversion. The serum and controls were added to microwells, were coated with brucella abortus LPS, at a diluted rate of $1 / 20$. Following the addition of the a multi-species horseradish peroxidase (HRP) conjugate and substrate solution (TMB) at a recommended strength, the plate was incubated and examined for the intensity of reaction with an automated ELISA reader at $450 \mathrm{~nm}$. The developed yellow color within a well after addition of stop solution indicates that the tested serum has antibodies to Brucella.

The test were valid if the mean OD value of positive and ratio of positive to negative controls were calculated as $\mathrm{OD}_{\mathrm{PC}}>0.350$ and $\mathrm{OD}_{\mathrm{PC}} / \mathrm{OD}_{\mathrm{NC}}$ $>3$, respectively. The result was interpreted by Seropositivity percentage (S/P \%) of $\geq 120 \%$ as positive and $\leq 110 \%$ as negative (Annex 4 ).

\subsection{Data Management and Analysis}

Data collected during the study period, risk factors believed to be associated with the occurrence of bovine brucellosis, serological and questionnaire survey were, entered into Microsoft Excel spreadsheet and analyzed using standard software programs (STATA version 9.0) and SPSS version 22. The sero-prevalence at individual animal level was calculated by dividing the number of positive animals by the total number of animals tested. Herd prevalence was calculated by dividing the number of herds with at least one reactor by the number of all herds tested. Pearson's Chi-square test was utilized to measure the association between the potential risk factors and the seropositivity. After the association of exposure variables with Brucella seropositivity was analyzed at individual animal level by the Chi-square test, those variables significantly associated with Brucella seropositivity (breed type, abortion history and RFM) were further analyzed by multivariable logistic regression. A multivariable logistic regression model was used to identify the potential risk factors associated with Brucella infection in animal and variables with a p-value of $<0.05$ (in Chi-square analysis) were included in the multivariable logistic regression model. Odds ratio (OR) was utilized to measure the degree of association between significant risk factors and sero-prevalence of bovine brucellosis. For statistical inference, p-value < 0.05 (at $5 \%$ level of significance) was considered as statistically significant.

\section{Results}

\subsection{Sero-Prevalence of Anti-Brucella Antibodies at Animal and Herd Level}

In the current study, a total of 384 cattle sera were collected from 145 males and 239 females, which includes 288 (75\%) indigenous and 96 (25\%) cross-breeds of indigenous zebu and Holstein Friesian were tested for bovine brucellosis. Of them, $13(3.39 \%)$ and $4(1.04 \%)$ were tested positive for Brucella antibody at individual level by RBPT and I-ELISA, respectively. The herd level sero-prevalence was $12(16.44 \%)$ and 4 $(5.48 \%)$ by RBPT and I-ELISA, respectively. The overall animal level sero-prevalence of bovine brucellosis of the present study was $1.04 \%$. The sero-prevalence distribution of bovine brucella infection in RBPT and I-ELISA tests for female (dairy cattle) animas with the prevalence of 12 (5.02\%) and 4 (1.67\%), respectively were presented in the following (Table 1).

Table1. Sero-prevalence of bovine Brucellosis by RBPT and I-ELISA tests

\begin{tabular}{|l|l|l|l|}
\hline & \multicolumn{3}{|c|}{ Sero-prevalence } \\
\hline $\begin{array}{l}\text { Types of } \\
\text { test }\end{array}$ & $\begin{array}{l}\text { Both } \\
\text { sexes }\end{array}$ & $\begin{array}{l}\text { Dairy } \\
\text { cattle }\end{array}$ & Herd-Level \\
\hline $\begin{array}{l}\text { RBPT } \\
\text { (positive) }\end{array}$ & $\begin{array}{l}13 \\
(3.39 \%)\end{array}$ & $\begin{array}{l}12 \\
(5.02 \%)\end{array}$ & $12(16.44 \%)$ \\
\hline $\begin{array}{l}\text { I-ELISA } \\
\text { (positive) }\end{array}$ & 4 & 4 & $4(5.48 \%)$ \\
\hline
\end{tabular}

\subsection{Chi-Square Analysis of Association of the Potential Risk Factors with Brucella Seropositivity Based on Sex}

According to the results obtained from the present study, $3.13 \%$ and $0.0 \%$ of seroprevalence were recorded in female and male animals, respectively. A Chi-square analysis revealed that breed type were significantly 
Sero-Prevalence of Bovine Brucellosis and its Associated Risk Factors in Becho District, South West Shewa, Oromia Regional State, Ethiopia

associated with the seropositivity of bovine brucellosis $(\mathrm{P}<0.05)$. Herd size, sex, age, management system, source of replacement stock, ways of keeping livestock and awareness

Table2. Association of potential risk factors with Brucella seropositivity based on sexes

\begin{tabular}{|c|c|c|c|c|c|c|}
\hline Variables & Level & No. tested & Prevalence \% & {$[95 \% \mathrm{CI}]$} & $\chi^{2}$ & P-value \\
\hline \multirow[t]{5}{*}{ Kebeles } & Boji & 54 & $1.85(1)$ & $-0.0178-0.0541$ & & \\
\hline & $\mathrm{A} / \mathrm{Guda}$ & 55 & $3.64(2)$ & $-0.0137-0.0864$ & 5.492 & 0.240 \\
\hline & Soyema & 121 & 0 & & & \\
\hline & A/Bune & 142 & $0.71(1)$ & $-0.0068-0.0208$ & & \\
\hline & T/Bolo & 12 & 0 & & & \\
\hline \multirow[t]{2}{*}{ Breed } & Local & 288 & $0.35(1)$ & $-0.0033-0.0102$ & 5.389 & $0.020^{*}$ \\
\hline & Cross & 96 & $3.13(3)$ & $-0.0038-0.0663$ & & \\
\hline \multirow[t]{2}{*}{ Sex } & Male & 145 & 0 & & \multirow{4}{*}{$\frac{2.452}{0.016}$} & \multirow[b]{2}{*}{0.117} \\
\hline & Female & 239 & $3.13(3)$ & $0.0003-0.0330$ & & \\
\hline \multirow[t]{2}{*}{ Age } & Young & 107 & $0.93(1)$ & $-0.0090-0.0277$ & & \multirow[t]{2}{*}{0.898} \\
\hline & Adult & 277 & $1.10(3)$ & $-0.0014-0.0230$ & & \\
\hline \multirow[t]{4}{*}{ Herd size } & Small & 56 & 0 & & \multirow{3}{*}{1.113} & \multirow{3}{*}{0.573} \\
\hline & Medium & 130 & $0.77(1)$ & $-0.0074-0.0228$ & & \\
\hline & Large & 198 & $1.50(3)$ & $-0.0019-0.0322$ & & \\
\hline & Extensive & 289 & $1.4(4)$ & $0.0003-0.0273$ & \multirow[t]{2}{*}{1.328} & \multirow[t]{2}{*}{0.249} \\
\hline $\begin{array}{l}\text { Management } \\
\text { system }\end{array}$ & $\begin{array}{l}\text { Semi- } \\
\text { intensive }\end{array}$ & 95 & 0 & & & \\
\hline \multirow{3}{*}{$\begin{array}{lr}\text { Source } & \text { of } \\
\text { replacement stock }\end{array}$} & Own farm & 38 & 0 & & \multirow{3}{*}{2.384} & \multirow{3}{*}{0.303} \\
\hline & Market & 147 & $2.1(3)$ & $-0.0025-0.0434$ & & \\
\hline & Both & 199 & $0.5(1)$ & $-0.0048-0.0149$ & & \\
\hline \multirow{2}{*}{$\begin{array}{l}\text { Ways of keeping } \\
\text { livestock }\end{array}$} & All together & 297 & $1.34 \%(4)$ & $0.0002-0.0266$ & \multirow[t]{2}{*}{1.184} & \multirow[t]{2}{*}{0.277} \\
\hline & Separating all & 87 & 0 & & & \\
\hline \multirow{3}{*}{$\begin{array}{l}\text { Awareness about } \\
\text { brucellosis }\end{array}$} & Yes & 12 & 0 & & \multirow{3}{*}{0.131} & \multirow{3}{*}{0.718} \\
\hline & No & 372 & $1.1 \%(4)$ & $0.0002-0.0212$ & & \\
\hline & Total & 384 & $1.04(4)$ & $0.0002-0.0206$ & & \\
\hline
\end{tabular}

$*$ : indicates significant at $p<0.05 ; \chi^{2}$-Pearson's Chi-square; CI: confidence interval

The following, table 3 shows the result of Chisquare test analysis of the association between risk factors and Brucella infection seropositivity in dairy cattle. It revealed that the presence of abortion history, retained fetal membrane and

Table3. Association of potential risk factors with Brucella seropositivity in dairy cattle

\begin{tabular}{|c|c|c|c|c|c|c|}
\hline Variables & Level & $\begin{array}{l}\text { No. } \\
\text { Tested }\end{array}$ & Prevalence $\%$ & $\begin{array}{ll}\text { [95\% } & \text { Conf. } \\
\text { Interval] } & \\
\end{array}$ & $\chi^{2}$ & $\begin{array}{l}\text { P- } \\
\text { value }\end{array}$ \\
\hline \multirow[t]{2}{*}{ Breed } & Local & 168 & $0.59(1)$ & $-0.005-0.017$ & 3.9965 & $0.046^{*}$ \\
\hline & Cross & 71 & $4.23(3)$ & $-0.005-0.089$ & & \\
\hline \multirow[t]{2}{*}{ Age } & Young & 75 & $1.30(1)$ & $-0.012-0.039$ & 0.0769 & 0.782 \\
\hline & Adult & 164 & $1.82(3)$ & $-0.002-0.038$ & & \\
\hline \multirow[t]{3}{*}{ Parity } & No parturition & 67 & 0 & & & \\
\hline & $\begin{array}{l}\text { Single } \\
\text { parturition }\end{array}$ & 49 & $1.10(1)$ & $-0.019-0.060$ & 1.6184 & 0.445 \\
\hline & Multi parturition & 123 & $2.43(3)$ & $-0.003-0.051$ & & \\
\hline \multirow[t]{2}{*}{ Pregnancy status } & Pregnant & 94 & $2.07(3)$ & $-0.002-0.044$ & 0.3501 & 0.055 \\
\hline & Non-pregnant & 145 & $1.06(1)$ & $-0.010-0.031$ & & \\
\hline \multirow[t]{2}{*}{ History of RFM } & Present & 28 & $7.14(2)$ & $-0.026-0.169$ & 5.7649 & $0.016^{*}$ \\
\hline & Not present & 211 & $0.94(2)$ & $-0.003-0.022$ & & \\
\hline \multirow[t]{2}{*}{ Abortion history } & Aborted & 23 & $17.4(4)$ & $0.014,0.333$ & 38.204 & $0.000 *$ \\
\hline & Non aborted & 216 & 0 & & & \\
\hline \multirow[t]{2}{*}{ Herd size } & \begin{tabular}{l|l} 
Small & \\
\end{tabular} & 33 & 0 & & 0.8963 & 0.639 \\
\hline & Medium & 74 & $1.35(1)$ & $-0.013-0.040$ & & \\
\hline
\end{tabular}

breed type were significantly associated with the seropositivity of bovine brucellosis $(\mathrm{p}<0.05)$ with Chi-square value of 38.2, 5.76 and 3.99 and Pvalue of $0.000,0.016$ and 0.046 , respectively. about brucellosis were insignificantly correlated $(\mathrm{P}>0.05)$ with the seropositivity of Brucella infection at individual animal level (Table 2). 
Sero-Prevalence of Bovine Brucellosis and its Associated Risk Factors in Becho District, South West Shewa, Oromia Regional State, Ethiopia

\begin{tabular}{|c|c|c|c|c|c|c|}
\hline & Large & 132 & $2.30(3)$ & $-0.002-0.048$ & & \\
\hline \multirow{2}{*}{$\begin{array}{l}\text { Management } \\
\text { system }\end{array}$} & Extensive & 178 & $2.24(4)$ & $0.001-0.044$ & 1.3941 & 0.238 \\
\hline & Semi-intensive & 61 & 0 & & & \\
\hline \multirow{3}{*}{$\begin{array}{l}\text { Ways of disposing } \\
\text { placenta/aborted } \\
\text { fetus }\end{array}$} & Deep burry & 10 & 0 & & & \\
\hline & $\begin{array}{ll}\text { Dispose } & \text { to } \\
\text { environment }\end{array}$ & 66 & $3.00(2)$ & $-0.011-0.072$ & 1.106 & 0.575 \\
\hline & $\begin{array}{l}\text { Allow to eaten } \\
\text { by carnivores }\end{array}$ & 163 & $1.23(2)$ & $-0.004-0.029$ & & \\
\hline \multirow{3}{*}{$\begin{array}{l}\text { Source of } \\
\text { replacement stock }\end{array}$} & Raise own farm & 23 & 0 & & 2.4909 & 0.288 \\
\hline & Market & 90 & $3.31(3)$ & $-0.0041-0.070$ & & \\
\hline & Both & 126 & $0.80(1)$ & $-0.0076,0.0235$ & & \\
\hline \multirow[t]{2}{*}{ Calving pen } & Yes & 29 & 0 & - & 5.618 & 0.454 \\
\hline & No & 210 & $1.92(4)$ & $0.000-0.037$ & & \\
\hline \multirow{2}{*}{$\begin{array}{l}\text { Ways of keeping } \\
\text { livestock }\end{array}$} & All together & 180 & $2.22(4)$ & $0.000-0.043$ & 1.333 & 0.248 \\
\hline & Separating all & 59 & 0 & & & \\
\hline \multirow{2}{*}{$\begin{array}{l}\text { Awareness about } \\
\text { brucellosis }\end{array}$} & Yes & 10 & 0 & & \multirow[t]{2}{*}{0.1776} & \multirow[t]{2}{*}{0.678} \\
\hline & No & 229 & $1.75(4)$ & $0.001-0.034$ & & \\
\hline
\end{tabular}

*: indicates significant at $p<0.05 ; \chi^{2}$-Pearson's chi-square; CI: confidence interval

\subsection{Multivariable Logistic Regression Analysis of Risk Factors Associated with Brucella Seropositivity}

The odds ratio indicated that cross-breed animals were 3.1 times more likely to develop brucellosis than indigenous animals. Regarding the effect of abortion, animals with the history of abortion had significantly higher prevalence (17.4\%) and OR indicated that 12.4 times more likely to develop brucellosis than animals without history of abortion. There was also a trend of increment in individual animal sero-prevalence with history of retained fetal membrane. The OR indicated that animals with the history of retained fetal membranes were 4.5 times more likely to develop brucellosis than animals without history of retained fetal membranes (Table 4).

Table4. Degree of association of potential risk factors with the Brucella infection in dairy cow by multivariable logistic regression

\begin{tabular}{|l|l|l|l|}
\hline Variables & Level & OR & {$[95 \%$ CI $]$} \\
\hline Breed & Local & 0.331 & $0.061-1.809$ \\
\hline & Cross & 3.065 & $1.694-5.543$ \\
\hline RFM & Present & 4.519 & $1.590-12.848$ \\
\hline & Absent & 0.562 & $0.211-1.499$ \\
\hline Abortion & Aborted & 12.37 & $8.037-19.034$ \\
\hline & Not aborted & - & - \\
\hline
\end{tabular}

OR: odds ratio; CI: confidence interval; RFM: retained fetal membrane

\section{DiscuSSION}

The overall sero-prevalence of Brucella antibodies determined with RBPT and I-ELISA in Becho district, Oromia regional state were $3.39 \%$ and $1.04 \%$, respectively. Since I-ELISA is the recommended diagnostic test for brucellosis with higher sensitivity and specificity (Getachew et al., 2016; Uzal et al., 1995), the overall seroprevalence of bovine brucellosis in the study area is $1.04 \%$. This low sero-prevalence is in agreement with the earlier report of (Meles and Kibeb, 2018) with the same prevalence in the Chencha district, GamoGofa zone, South-Eastern Ethiopia, (Adugna et al. 2013; Kang'ethe et al., 2007) with $1 \%$ in the Benishangul Gumuz region of North-Western Ethiopia and Nairobi, Kenya, respectively. It is comparable with other previous reports from different part of Ethiopia; (Terefe $e t$ al., 2017) with $1.3 \%$ in Eastern Ethiopia, (Degefu et al., 2011) with $1.38 \%$ in Jijjiga Zone of Somalia regional state, (Geresu et al., 2016; Gumi et al., 2013) with $1.4 \%$ in Bishoftu and Asella, central Ethiopia and South-Eastern pastoral livestock of the country, respectively, (Mekonnen et al., 2010) with $1.49 \%$ in Western Tigray Zone, North West Ethiopia, (Tesfaye et al., 2011) with $1.5 \%$ in Addis Ababa dairy farms, (Asmare et al., 2010) with $1.66 \%$ in Sidama Zone, Southern Ethiopia, (Yohannes et al., 2012) with $1.97 \%$ in Guto-Gida district, East Wollega zone, (Alemu et al., 2014) with $2 \%$ in Eastern Shewa Zone, central Ethiopia.

On the other hand, there were reports with a relatively higher sero-prevalence rate of bovine 
brucellosis in other parts of the country; (Dinka and Chala, 2009) with $11.2 \%$ in pastoral and agro-pastoral areas of East Shewa Zone, (Kebede et al., 2008) with $11.0 \%$ in Wuchale-Jida district, central Ethiopia, (Megersa, et al., 2011a) with $10.6 \%$ in Borana, (Eticha et al., 2018) with 9.87\% in Asella organized dairy farm, South East Ethiopia, (Megersa et al., 2012) with $8.0 \%$ in pastoral region of the country, (Haileselassie et al., 2011) with $4.9 \%$ in Western Tigray, (Tibesso et al., 2014) with $4.3 \%$ in Adami Tulu, central Ethiopia, (Berhe et al., 2007) with $3.19 \%$ in the extensive cattle production system of Tigray region, Northern part of the country, (Ibrahim et al., 2010) with $3.1 \%$ in Jimma Zone of Oromia region. Similarly, relatively higher seroprevalence were reported in other African countries; (Angara et al., 2004) with $24.5 \%$ in Sudan; (Mai et al., 2012) with $24.0 \%$ in Nigeria, (Mensah et al., 2011) with $21.9 \%$ in Ghana, (Matope et al., 2011) with 5.6\% in Zimbabwe, (Swai and Schoonman, 2010) with $5.3 \%$ in Tanzania.

On the other hand lower sero-prevalence was recorded in certain part of the country: (Garoma, 2018 ) with $0.73 \%$ in Jimma zone, Western Ethiopia, (Sarba et al., 2016) with $0.49 \%$ in Western Shewa, (Asmare et al., 2007) with 0.4\% in urban dairy farms of Northern Ethiopia and Sebeta while (Asmare et al., 2013) in Nazareth, Gondar, and Mekele (possibly due to low sample size in their study), (Bashitu et al., 2015) with $0.2 \%$ in Debrebirhan and Ambo Towns, (Degefa et al., 2011) with $0.05 \%$ in Arsi zone, and (Lakew et al., 2019; Alem and Solomon, 2002) were unable to find even a single positive reactor in intensive dairying farms in Fafan Zone of Ethiopian-Somali and central Ethiopia, respectively.

In this study breed was supposed to be one of the risk factors, consequently sero-prevalence was found to be higher in cross-breed animals $(3.13 \%)$ than local breeds $(0.35 \%)$. This difference was statistically significant $(\mathrm{p}<0.05)$ which is similar to (Ndazigaruye et al., 2018; Eticha et al., 2018; Minda et al., 2016; Alemu et al., 2014; Yohannes et al., 2012; Jergefa et al., 2009) reported significant variation on serological prevalence of brucellosis with higher prevalence in cross-bred than in local ones. In contrast to this finding, (Geresu et al., 2016a; Deselegn and Gangwar, 2011) reported that, the significance of breed might be due to the origin of the animal from the previously infected or exposed herds and limitation in sample sizes of local breeds.

Sex has been one of the risk factors affecting susceptibility of cattle to Brucella abortus infection (Yohannes et al., 2012). Seropositivity in females $(3.13 \%)$ was indicated in study area where as no seropositive in males; this finding is in agreement with previous report by (Garoma, 2018; Adugna et al., 2013). This implies that female cattle were at higher risk than males. The lower prevalence of male reactors in this study could be due to smaller number of males tested as compared to female and it was also reported that the serological response of male animal to Brucella infection is limited (Mohammed, 2009; Berhe et al., 2007). In addition, it has also been reported that infected male animals are usually found to show low antibody titers (Godfroid et al., 2002).

It is well known that sexually mature animals are more susceptible to Brucella abortus infection (Garoma, 2018; Berhe et al., 2007), which could be explained by the fact that susceptibility increased during sexual maturity and gestation period due to the influence of sex hormones and elevation of fetal fluid and erythritol sugar in the placenta. This stimulates the growth and multiplication of the bacteria in the reproductive organs (Asgedom et al., 2016; Hileselassie et al., 2008; Radostitis et al., 2007). Accordingly a higher sero-prevalence $(3.13 \%)$ in older age category (greater than 36 months) and seronegativity in younger age category (6 months - 36 months) was found in present study. This finding was in consistent with report of (Ibrahim et al., 2010; Abebe et al., 2008; Hailemelekot et al., 2007).

The existence of previous history of abortion and retained fetal membrane was, as expected, significantly associated $(\mathrm{p}<0.05)$ with Brucella seropositivity in the present study. A seroprevalence of $17.4 \%$ and $7.14 \%$ were recorded for the occurrence of previous abortion and RFM in this study areas based on questionnaire survey. This finding was consistent with (Tolosa, 2004) who reported $17.6 \%$ in selected sites of Jimma Zones and (Geresu et al., 2016) 17.39\% in Asella and Bishoftu. This could be explained by the fact that abortions and/or retained placenta are typical outcomes of brucellosis (Eticha et al., 2018; Geresu et al., 2016; Alemu et al., 2014). Other studies have also shown a significant association between seropositivity, and history of abortion and RFM (Alemu et al., 2014; Adugna et al., 
2013; Ibrahim et al., 2010; Tolosa et al., 2008). Similarly, a number of studies in different African countries also show that individual animal brucellosis sero-prevalence correlates with the presence of abortions (Muma et al., 2012; Schelling et al., 2003; McDermott et al., 2002; Kubuafor et al., 2000).

On the basis of parity, the difference observed in sero-prevalence was statistically insignificant. Similar observations were made by (Geresu et al., 2016a; Berhe et al., 2007). Although there is insignificant association between parity and brucellosis seropositivity, the higher seroprevalence was observed in multi-parturition $(2.43 \%)$ than single-parturition cattle $(1.10 \%)$ in the study areas. The higher sero-prevalence of brucellosis in the multi-parturition cattle of this study was in line with (Geresu et al., 2016; Asmare et al., 2013) who reported $2.41 \%$ and $2.5 \%$ in multi- parturition dairy cattle respectively.

Herd size is another risk factor that affects occurrence of brucellosis (Yohannes et al., 2013). In this study significant differences of Brucella sero-prevalence among three herd size categories, which was $1.5 \%, 0.77 \%$ and $0 \%$ in the large (>30 animals), medium (16-30 animals) and small (1-15 animals) herds, respectively. This revealed that comparatively higher seropositivity in the larger herd categories, which agreed with the findings of (Geresu et al., 2016; Berhe et al., 2007). However, in contrary to this, (Kebede et al., 2008) reported that the risk of Brucella seropositivity was independent of herd size in small holder farms from Wuchale-Jida district of east Wollega Zone of Ethiopia. Higher seropositivity in large herd size can be explained by the fact that an increase in herd size is usually accompanied by an increase in stocking density, one of the determinants for exposure to Brucella infection especially following abortion or calving (Crawford et al., 1990; Geresu et al., 2016).

\section{CONCLUSION AND RECOMMENDATIONS}

Bovine brucellosis has a major impact on human health, besides causing significant economical losses in dairy industry. The present study revealed that the overall sero-prevalence of bovine brucellosis in smallholders of Becho district was relatively low at individual animal and herd level. There was strong association between abortion, retained fetal membrane and breed seropositivity for bovine brucellosis in the study area. Moreover, the finding demonstrated a poor understanding of brucellosis among communities and a high level of risky practice being undertaken that is inevitably, might result in an increased transmission between animals and zoonoses in risky group personnels. Therefore, on basis of the above conclusion the following points were recommended:

$>$ Awareness creation among the people about the impact of the diseases, modes of transmission, risk factors and methods of prevention of the diseases should be undertaken in the study area.

$>$ Collaboration as in one health approach needed to be introduced since neither veterinarian alone nor physician alone could not perform all approaches to control such important disease in the country.

$>$ Further detail and fully fledged research is very important to have full and all round information regarding epidemiology of the brucellosis.

\section{REFERENCES}

[1] Abebe, A., Kassa, T., Degefu, T., and Hassen, E. (2008): Investigation on sero-prevalence of bovine brucellosis and related major reproductive health disorders in Ada'a Liben Dairy Cooperative. Ethiopian Veterinary Journal, 12(2): 19-31.

[2] Adugna, K. E., Agga, G. E., and Zewde, G. (2013): Seroepidemiological survey of bovine brucellosis in cattle under a traditional production system in western Ethiopia. Technical and Scientific Review, 32(3): 765773.

[3] Alem, W., and Solomon, G. (2002): A retrospective sero-epidemiology study of Bovine Brucellosis in different Production Systems in Ethiopia. In Proceeding of 16th Annual Conference, June 5-6, Addis Ababa, Ethiopia. Pp: 53-57

[4] Alemu, F., Admasu, P., Feyera, T., and Niguse, A. (2014): Sero-prevalence of bovine brucellosis in eastern Showa, Ethiopia. Academic Journal of Animal Diseases, 3(3): 27-32.

[5] Angara, T. E., Ismail, A., Agab, H., and Saeed, N. (2004): Sero-prevalence of bovine brucellosis in Kuku Dairy Scheme, Khartoum North, Sudan.

[6] Asgedom, H., Damena, D., and Duguma, R. (2016): Seroprevalence of bovine brucellosis and associated risk factors in and around Alage district, Ethiopia, Springer Plus, 5:851.

[7] Asmare, K., Prassad, S., Asfaw, Y., Gelaye, E., Ayelet, G., and Zeleke, A. (2007): Seroprevalence of brucellosis in cattle and high risk animal health professionals in Sidama Zone, Southern. Ethiopian Veterinary Journal, 11: 6984. 
[8] Asmare, K., Sibhat, B., Molla, W., Ayelet, G., Shiferaw, J., Martin, A. D., Godfroid, J. (2013): The status of bovine brucellosis in Ethiopia with special emphasis on exotic and cross bred cattle in dairy and breeding farms. Acta Tropica, 126(3): 186-192.

[9] Bashitu L, Afera B, Tuli G, Aklilu F (2015): Sero-Prevalence Study of Bovine Brucellosis and its Associated Risk Factors in Debrebirhan and Ambo Towns. Journal of Advanced Dairy Research, 3(1):131.

[10] Belihu, K. (2002): Analysis of dairy cattle breeding practices in selected areas of Ethiopia. PhD Thesis, Humboldt University, Berlin.

[11] Berhe, G., Belihu, K., and Asfaw, Y. (2007): Seroepidemiological investigation of bovine brucellosis in the extensive cattle production system of Tigray region of Ethiopia. International Journal of Applied Research in Veterinary Medicine, 5(2): 65.

[12] Central Statistical Agency (CSA) (2013): "Population project of Ethiopia for all regions at wereda level from 2014-2017", Addis Ababa, Ethiopia.

[13] Crawford, R. P., Huber, J. D., and Adams, B. S. (1990): Epidemiology and surveillance. Animal Brucellosis, Florida: CRC Press Inc., 131-148.

[14] Degefa, T., Duressa, A., and Duguma, R. (2011): Brucellosis and Some Reproductive Problems of Indigenous Arsi Cattle in Selected Arsi Zone's of Oromia Regional State, Ethiopia, Global Veterinarian, 7 (1): 45-53.

[15] Degefu, H., Mohamud, M., Hailemelekot, M., and Yohannes, M. (2011): Sero-prevalence of bovine brucellosis in agro pastoral areas of Jijjiga zone of Somali National Regional State, Eastern Ethiopia. Ethiopian Veterinary Journal, 15(1): 37-47.

[16] Deselegn, T. B., and Gangwar, S. K. (2011): Seroprevalence study of bovine brucellosis in Assela government dairy farm of Oromia Regional State, Ethiopia. International Journal of Science National, 2:692-697

[17] Dinka, H., and Chala, R. (2009): Seroprevalence study of bovine brucellosis in pastoral and agro-pastoral areas of East Showa Zone, Oromia Regional State, Ethiopia. American-Eurasian Journal of Agricultural and Environmental Science, 6(5): 508-512.

[18] Eticha, E., Solomon, H., lemma, D., and Abera, B. (2018): Prevalence and risk analysis of bovine brucellosis in Asella organized dairy farm, Oromia Regional State, South East Ethiopia, Journal of Veterinary Medicine and Animal Health, 10(10): 245-249.

[19] Garoma, T. (2018): Seroepidemology of bovine brucellosis in Horro Guduru Animal Production and Research Center, and its surroundings, Western Ethiopia. MSc Thesis, Faculty of
Veterinary Medicine, Addis Ababa University, Debre Zeit, Ethiopia. Pp: 1-60.

[20] Geresu, M. A., Ameni, G., Tuli, G., Arenas, A., and Kassa, G. M. (2016): Seropositivity and risk factors for Brucella in dairy cows in Asella and Bishoftu towns, Oromia Regional State, Ethiopia. African Journal of Microbiology Research, 10(7): 203-213.

[21] Getachew, T., Getachew, G., Sintayehu, G., Getenet, M., and Fasil, A., (2016): Bayesian Estimation of Sensitivity and Specificity of Rose Bengal, Complement Fixation, and Indirect ELISA Tests for the Diagnosis of Bovine Brucellosis in Ethiopia, Hindawi Publishing Corporation Veterinary Medicine International, Article ID 8032753.

[22] Godfroid, J., Saegerman, C., Wellemans, V., Walravens, K., Letesson, J., Tibor, A., Mc Millan, A., Spencer, S., Sanna, M., Bakker, D., Pouillot, R., and Garin-Bastuji, B. (2002): How to substantiate eradication of bovine brucellosis when specific serological reaction occur in the course of brucellosis testing, Veterinary Microbiology, 90: 461-477.

[23] Gumi, B., Firdessa, R., Yamuah, L., Sori, T., Tolosa, T., Aseffa, A., 1, E. (2013): Seroprevalence of Brucellosis and Q-Fever in southeast Ethiopian pastoral livestock. Journal of Veterinary Science and Medical Diagnosis, 2(1).

[24] Hailemelekot, M., Kassa, T., and Asfaw, Y. (2007): Sero-prevalence study of brucellosis in Bahirdar milkshed, North-western Amhara Region. Ethiopian Veterinary Journal, 11: 4965 .

[25] Haileselassie, M., Kalayou, S., Kyule, M., Asfaha, M., and Belihu, K. (2011): Effect of Brucella infection on reproduction conditions of female breeding cattle and its public health significance in Western Tigray, northern Ethiopia. Veterinary Medicine International, 21(1).

[26] Ibrahim, N., Belihu, K., Lobago, F., and Bekana, M. (2010): Sero-prevalence of bovine brucellosis and its risk factors in Jimma zone of Oromia Region, South-western Ethiopia. Tropical Animal Health and Production, 42(1): 35.

[27] Jergefa, T., Kelay, B., Bekana, M., Teshale, S., Gustafson, H., and Kindahl, H. (2009): Epidemiological study of bovine brucellosis in three agro-ecological areas of central Oromiya, Ethiopia. Revue Scientifique et Technique, 28(3): 933.

[28] Kang'ethe, E. K., Ekuttan, C. E., Kimani, V. N., and Kiragu, M. W. (2007): Investigations into the prevalence of bovine brucellosis and the risk factors that predispose humans to infection among urban dairy and non-dairy farming 
Sero-Prevalence of Bovine Brucellosis and its Associated Risk Factors in Becho District, South West Shewa, Oromia Regional State, Ethiopia

households in Dagoretti Division, Nairobi, Kenya. East African Medical Journal, 84(11): 96-100.

[29] Kebede, T., Ejeta, G., and Ameni, G. (2008): Sero-prevalence of bovine brucellosis in smallholder farms in central Ethiopia (WuchaleJida district). Revue de Médecine Vétérinaire, 159(1): 3 .

[30] Kubuafor, D. K., Awumbila, B., and Akanmori, B. D. (2000): Sero-prevalence of brucellosis in cattle and humans in the Akwapim-South district of Ghana: public health implications. Acta Tropica, 76(1), 45-48.

[31] Lakew, A., Hiko, A., Abraha, A., Hailu, (2019): Sero-prevalence and community awareness on the risks associated with Livestock and Human brucellosis in selected districts of Fafan Zone of Ethiopian-Somali National Regional State, Veterinary and Animal Science, 7:100047.

[32] Matope, G., Bhebhe, E., Muma, J. B., Oloya, J., Madekurozwa, R. L., Lund, A., and Skjerve, E. (2011): Sero-prevalence of brucellosis and its associated risk factors in cattle from smallholder dairy farms in Zimbabwe. Tropical Animal Health and Production, 43(5): 975-982.

[33] McDermott , J. J., and Arimi, S. M. (2002): Brucellosis in sub-Saharan Africa: epidemiology, control and impact. Veterinary Microbiology, 90(1-4): 111-134.

[34] Megersa, B., Biffa, D., Abunna, F., Regassa, A., Godfroid, J., Skjerve, E. (2011a): Seroprevalence of brucellosis and its contribution to abortion in cattle, camel, and goat kept under pastoral management in Borana, Ethiopia, Tropical Animal Health and Production, 43(3): 651-656.

[35] Megersa, B., Biffa, D., Niguse, F., Rufael, T., Asmare, K., and Skjerve, E. (2011b): Cattle brucellosis in traditional livestock husbandry practice in Southern and Eastern Ethiopia, and its zoonotic implication. Acta Veterinaria Scandinavica, 53(1): 24

[36] Megersa, B., Biffa, D.,Abunna, F.,Regassa, A.,Godfroid, J., and Skjerve, E. (2012): Seroepidemiological study of livestock brucellosis in a pastoral region. Epidemiology and Infection, 140(5): 887-896.

[37] Megid, J., Luis Antonio Mathias, L. A., and Robles, C. A. (2010): Clinical Manifestations of Brucellosis in Domestic Animals and Humans, The Open Veterinary Science Journal, 4: 119126.

[38] Mekonnen, H., Kalayou, S., and Kyule, M. (2010): Serological survey of bovine brucellosis in barka and arado breeds (Bos indicus) of
Western Tigray, Ethiopia. Preventive Veterinary Medicine, 94(1-2): 28-35.

[39] Meles, Y., and Kibeb, L. (2018): Seroprevalence of bovine brucellosis in and around Chencha district, GomoGofa Zone, South Eastern Ethiopia, World Journal of Pharmaceutical Research, 7(1): 1448-1460.

[40] Mensah, G. I., Addo, k. k., Aning, k. G., Nartey, N., Nipah, G. K., Smits, H. L. (2011): Brucella abortus antibodies in raw cow milk collected from Kraals within the Coastal Savannah Zone of Ghana. In: Journal of Basic and Applied Scientific Research., 1(8): 942-947.

[41] Minda, A. G., Gobena, A., Tesfu, k., Getachew, T., Angella, A., Gezahegne, M. K. (2016): Seropositivity and risk factors for Brucellain dairy cows in Asella and Bishoftu towns, Oromia Regional State, Ethiopia. African Journal of Microbiology.Research, 10(7): 203213.

[42] Mohammed, H. (2009): Seroprevalence of small ruminant brucellosis in and around Jijiga. DVM thesis, School of Veterinary Medicine, Jimma University, Jimma, Ethiopia.

[43] Muma, J. B., Pandey, G. S., Munyeme, M., Mumba, C., Mkandawire, E., and Chimana, H. M. (2012): Brucellosis among smallholder cattle farmers in Zambia. Tropical Animal Health and Production, 44(4): 915-920.

[44] National Meteorology Service Agency (NMSA) (2011):"Annual Report", Addis Ababa, Ethiopia.

[45] Ndazigaruye, G., Mushonga, B., Kandiwa, E., Samkange, A., and Segwagwe, B. (2018): Prevalence and risk factors for brucellosis seropositivity in catle in Nyagatare District, Eastern Province, Rwanda', Journal of the South African Veterinary Association, 89(0): 1625.

[46] OIE (2008): Manual of diagnostic tests and vaccines for terrestrial animals. Organization of International Des Epizooties, Paris, France, Pp: 1092-110614

[47] Radostitis, O. M., Gay, C. C., Hinchcliff, K. W., and Constable, P. D. (2007): Veterinary medicine. A text book of the diseases of cattle, horses, sheep, pigs and goats. 10th Edn. Saunders Elsevier; Edinburgh, London, New york. Oxford, Philadelphia, St. Louis, Sydney, Toronto.

[48] Sarba, E. J., Getaneh, A. M., Borena, B. M., Ambecha, H. A., Berecha, M. S., Eteya, W. T., and Tola, G. K. (2016): Sero-prevalence and associated risk factors of Brucellosis in dairy cattle in selected towns of West Shewa, Ethiopia. Bulletin of Animal Health and Production in Africa, 64(4): 387-395. 
[49] Schelling, E., Diguimbaye, C., Daoud, S., Nicolet, J., Boerlin, P., Tanner, M., and Zinsstag, J. (2003): Brucellosis and Q-fever seroprevalences of nomadic pastoralists and their livestock in Chad. Preventive Veterinary Medicine, 61(4): 279-293.

[50] Shiferaw, Y., Tenhagen, B.-A., Bekana, M., and Kassa, T. (2003): Reproductive performance of crossbred dairy cows in different production systems in the central highlands of Ethiopia. Tropical Animal Health and Production, 35(6): 551-561.

[51] Swai, E.S., and Schoonman, L. (2010): The Use of Rose Bengal Plate Test to Asses Cattle Exposure to Brucella Infection in Traditional and Smallholder Dairy Production Systems of Tanga Region of Tanzania, Veterinary Medicine International, Article ID 837950.

[52] Tekle, M. (2016): Seroprevalence of brucellosis and isolation of brucella from small ruminants that had history of recent abortion in selected kebeles of amibara district, afar region, MSc Thesis. Faculty of Veterinary Medicine, Addis Ababa University, Debre Zeit, Ethiopia.

[53] Terefe, Y., Girma, S., Mekonnen, N., Asrade, B. (2017): Brucellosis and associated risk factors in dairy cattle of eastern Ethiopia, Tropical Animal Health and Production, 49(3): 599-606.

[54] Tesfaye, G., Tsegaye, W., Chanie, M., and Abinet, F. (2011): Sero-prevalence and associated risk factors of bovine brucellosis in
Addis Ababa dairy farms. Tropical Animal Health and Production, 43(5): 1001-1005.

[55] Tesfaye, G., Wondimu, A., Asebe, G., Regasa, F., and Mamo, G. (2017): Sero-prevalence of Bovine Brucellosis in and Around Kombolcha, Amhara Regional State, Ethiopia, Mycrobacterial Disease, 7: 2.

[56] Thrusfield, M. (2018): Veterinary Epidemiology $4^{\text {th }}$ Edition. John Wiley and Sons, Pp: 276.

[57] Tibesso, G., Ibrahim, N., and Tolosa, T. (2014): Sero-prevalence of bovine and human brucellosis in Adami Tulu, Central Ethiopia. World Applied Sciecnce Journal, 31: 776-780.

[58] Tolosa, T. (2004). Seroprevalence study of bovine brucellosis and its public health significance in selected sites of Jimma Zone, Western Ethiopia. MSc Thesis. Faculty of Veterinary Medicine, Addis Ababa University, Debre Zeit, Ethiopia. Pp: 9

[59] Uzal, F.A., Carrasco, A. E., Echaide, S., Nielsen, K., Robles, C. A., (1995): Evaluation of an indirect ELISA for the diagnosis of bovine brucellosis, Journal of Veterinary Diagnosis Investigation, 7: 473-475.

[60] Yohannes, M., Degefu, H., Tolosa, T., Belihu, K., Cutler, R. R., and Cutler, S. J. (2013): Brucellosis in Ethiopia. African Journal of Microbiology Research, 7(14): 1150-1157.

[61] Yohannes, M., Mersha, T., Degefu, H., Tolosa, T., and Woyesa, M. (2012): Bovine Brucellosis: Serological Survey in Guto-Gida District, East Wollega Zone, Ethiopia, Global Veterinarian, 8(2): 139-143.

Citation: Dinknesh Teka, Biniam Tadesse, Getachew Kinfe, Yifat Denberga. Sero-Prevalence of Bovine Brucellosis and its Associated Risk Factors in Becho District, South West Shewa, Oromia Regional State, Ethiopia. ARC Journal of Animal and Veterinary Sciences. 2019; 5(2):35-45. doi: dx.doi.org/10.20431/24552518.0502005.

Copyright: (C) 2019 Authors. This is an open-access article distributed under the terms of the Creative Commons Attribution License, which permits unrestricted use, distribution, and reproduction in any medium, provided the original author and source are credited. 